\title{
NILAI SOSIAL PADA NOVEL PADANG BULAN KARYA ANDREA HIRATA (KAJIAN SOSIOLOGI SASTRA)
}

\author{
Afrianus Lapu \\ (Pendidikan Bahasa dan Sastra Indonesia, Fakultas keguruan dan ilmu pendidikan, \\ Universitas PGRI Adi Buana Surabaya) \\ afrilapu07@gmail.com \\ Indayani \\ (Pendidikan Bahasa dan Sastra Indonesia, Fakultas keguruan dan ilmu pendidikan, \\ Universitas PGRI Adi Buana Surabaya) \\ Indayani16a@gmail.com
}

\begin{abstract}
The selection of this novel as an object of research is based on a thought that the novel is lifted from human life to fight for its life, amidst the dynamics of social life, patience, laughter, devout worshipers, diligently working and learning, Shortcuts of love, caring. This study aims to describe the social values contained in the novel "Padang Bulan" by Andrea Hirata. The theory used in this research is Sociology Literature. The subject of this research is the novel "Padang Bulan" by Andrea Hirata. The object of this study is the social value contained in the novel "Padang Bulan" by Andrea Hirata and as literary learning material. Data were analyzed using qualitative descriptive techniques. The results of this study are social values in the novel "Padang Bulan" by Andrea Hirata. The variety of works consists of, patience, trust, worship, helpers, diligent work and study, love and care, all of these social values are very appropriate for student character development.
\end{abstract}

Keywords: social values, Padang Bulan novel, and Andrea Hirata.

\section{PENDAHULUAN}

Nilai sosial adalah nilai yang dianut oleh suatu masyarakat, mengenai apa yang dianggap baik dan apa yang dianggap buruk oleh masyarakat. Untuk menentukan sesuatu itu dikatakan baik atau buruk, pantas atau tidak pantas harus melalui proses menimbang. Hal ini tentu sangat dipengaruhi oleh kebudayaan yang dianut masyarakat. Tak heran apabila antara masyarakat yang satu dan masyarakat yang lain terdapat perbedaan tata nilai.

Nilai sosial selalu menjadi isu yang menarik untuk dibicarakan. Keberadaan nilai sosial yang agung ini tidak hanya mampu mempengaruhi kelangsungan hidup manusia. Namun, nilai-nilai ini juga mampu melahirkan sesuatu yang selalu hidup dalam setiap pemikiran, kajian, dan tindakan praktis dari masa ke masa.

Nilai sosial selalu diidamkan oleh setiap umat manusia dalam menciptakan sebuah tahta tatanan teratur, dinamis, dan progresif. Pemahaman teori-teori atau pengetahuan ilmiah yang begitu beragam. Meskipun terdapat berbagai aliran filsafat dan agama yang secara ilmiah dan spekulatif memaparkan pengertian tentang eksistensi manusia, ada titik temu dan prinsipprinsip pokok yang dipakai bersama tentang pengertian eksistensi manusia, yaitu sosiologi sastra. 
Adanya permasalahan-permasalahan dalam masyarakat yang merupakan cerminan susahnya mewujudkan nilai ideal dari sosial terjadi hampir diseluruh masyarakat global.

Kehidupan sosial merupakan suatu hal penting yang tidak terlepas dari kehidupan bermasyarakat, begitupun seorang makhluk manusia tentunya yang merupakan mahkluk yang saling membutuhkan satu sama lain di kehidupan sosial dalam setiap harinya. Manusia selalu membutuhkan satu sama lainnya untuk saling melengkapi disetiap sisi kehidupannya. Begitu pula yang terjadi pada karya-karya sastra yang mencoba menggambarkan kehidupankehidupan sosial masyarakat yang dikemas dalam bentuk karya sastra novel, cerpen dan lainnya.

Sastra merupakan wujud gagasan seseorang melalui pandangan terhadap lingkungan sosial yang berada di sekelilingnya dengan menggunakan bahasa yang indah. Sastra hadir sebagai hasil perenungan pengarang terhadap fenomena yang ada. Sastra sebagai karya fiksi memiliki pemahaman yang lebih mendalam, bukan hanya sekadar cerita khayal atau angan dari pengarang saja, melainkan wujud dari kreativitas pengarang dalam menggali dan mengolah gagasan yang ada dalam pikirannya. Karya sastra mampu memberikan kepuasan estetik dan intelektual bagi masyarakat pembaca. Akan tetapi, sering terjadi bahwa karya sastra tidak dapat dipahami dan dinikmati sepenuhnya oleh sebagian besar masyarakat pembaca (Waluyo, 2002:68).

Karya satra adalah seni bahasa yang bernaung di bawah apa yang imajinasi. Berbagai masalah dalam kehidupan difiksikan sesuai dengan pemikiran, keyakinan, keinginan, dan fantasi penciptanya. Karya sastra tersebut lahir sejalan dengan munculnya bahasa yang di pakai umat manusia, baik lisan maupun tulisan. Karena itu, karya sastra juga berkembang sejalan dengan kebudayaan manusia. Semakin maju kebudayaan manusia semakin maju kesusatraanya. Tinggi rendahnya kebudayaan dan peradaban suatu bangsa, antara lain, juga dapat dilihat dari satra yang dihasilkan oleh bangsa tersebut. Karya satra, pada setiap tempat dan waktu, akan mencerminkan kondisi masyarakatnya dalam berbagai aspek (Anwar, 2013:1).

Karya sastra merupakan cerminan kehidupan masyarakatnya. Pandangan ini sudah terbentuk di masa Plato dan Aristoteles dengan teori mimetiknya. Pada masa-masa selanjutnya, terutama setelah disiplin sosiologi sastra berkembang, semakin kukuh hubungan antara karya sastra dengan kondisi masyarakat. Teori mimetik "pada prinsipnya menganggap karya seni sebagai pencerminan, peniruan, atau pun pembayangan realitas", (Teeuw,1984:224).

Menurut Rafiek (2013:2), pengkajian sastra adalah mengkaji karya sastra secara mendalam dengan menggunakan teori sastra dan teknik analisis sastra yang tepat. Mengkaji sastra berarti menelaah karya sastra dengan menganalisis dan membahas data-data berupa kutipan kalimat atau paragraf yang mengandung masalah atau topik yang hendak kita jawab atau uraikan.

Pernyataan diatas menyimpulkan bahwa karya sastra tidak lepas dari kehidupan manusia yang berhubungan dengan kebudayaan, agama, serta ekonomi masyarakat serta norma-norma yang ada di 
masyarakat. Menurut Green, nilai sosial merupakan nilai yang digunakan sebagai kesadaran yang relatif berlangsung dan disertai emosi yang ada terhadap objeknya serta ide dari setiap individu.

Menurut Wiliams, nilai sosial adalah hal yang menyangkut kesejahteraan bersama melalui consensus yang efektif diantara mereka, sehingga nilai-nilai sosial dijunjung tinggi oleh banyak orang. Tujuan ini secara lebih luas dimaksudkan membentuk kepribadian mahasiswa yang memiliki cakrawala berpikir yang analitis, dialektik, inovatif, persuasif, dan terampil dalam mengimplementasikan kreasinya pada masyarakat secara relevan.

Dalam tulisan ini, penulis bermaksud mendeskripsikan nilai sosial yang ada pada novel Padang Bulan karya Andrea Hirata. Pemilihan novel ini sebagai objek penelitian didasarkan atas suatu pemikiran bahwa novel ini diangkat dari kehidupan manusia untuk memperjuangkan hidupnya, di tengah dinamika kehidupan sosial, kesabaran, tawaqal, taat beribadah, penolong, rajin bekerja dan belajar, cinta kasih, kepedulian.Novel Padang Bulan karya Andrea Hirata ini lebih banyak mengungkap tentang kehidupan manusia. Persoalan sosial yang terdapat dalam novel Padang Bulan karya Andrea Hirata ialah upaya manusia memperjuangkan hidup di tengah-tengah penderitaan.

Nilai sosial adalah nilai yang dianut oleh suatu masyarakat, mengenai apa yang dianggap baik dan apa yang dianggap buruk oleh masyarakat. Manusia merupakan makhluk yang tertinggi di antara makhluk ciptaan Tuhan, sehingga nilai-nilai sosial itu mencerminkan kedudukan manusia sebagai mahkluk tertinggi di antara mahkluk-mahkluk lainnya. Seseorang yang mempunyai nilai sosial yang tinggi menghendaki masyarakat memiliki sikap dan perilaku sebagai layaknya manusia. Sebaliknya dia tidak menyukai sikap dan perilaku yang sifatnya merendahkan manusia lain. Di antara sistem nilai yang ada di masyarakat salah satu di antaranya adalah nilai sosial. Nilai sosial adalah patokan normatif yang mempengaruhi manusia dalam menentukan pilihanya diantara cara-cara tindakan alternatif (Kuperman, via mulyana, 2004). Seperti sosiologi pada umumnya, Kuperman memandang norma sebagai salah satu bagian terpenting dari kehidupan sosial sebab dengan penegakan norma seorang dapat merasa tenang dan terbebas dari segala tuduhan masyarakat yang akan merugikan dirinya.

Untuk menentukan sesuatu itu dikatakan baik atau buruk, pantas atau tidak pantas harus melalui proses menimbang.Hal ini tentu sangat dipengaruhi oleh kebudayaan yang dianut masyarakat. Tak heran apabila antara masyarakat yang satu dan masyarakat yang lain terdapat perbedaan tata nilai. Menurut Kattsoff (dalam Sagala, 2013:5), mengemukakan dengan tiga macam cara: (1) nilai sepenuhnya berhakikat subjektif. Ditinjau dari sudut pandang ini, nilai merupakan reaksi-reaksi yang diberikan oleh manusia sebagai pelaku dan keberadaanya tergantung pengalaman-pengalamanya, (2) nilai merupakan kenyataan-kenyataan ditinjau dari ontolog, namun tidak terdapat dalam ruang dan waktu. Nilai merupakan esensi-esensi logis yang dapat diketahui melalui akal, pendirian ini dinamakan objektivisme 
logis, dan (3) nilai merupakan unsurunsur objektif yang menyusun kenyataan disebut objektivisme metafisika. Akal berperan penting untuk mengetahui dan menentukan nilai suatu objek apakah mengandung nilai objektif atau subjektif. Misalnya, ditampakkan pada perilaku manusia baik secara individu maupun komunitas, atau nilai suatu benda yang dapat ditentukan kualitas kegunaannya. Hal demikian tentunya juga berlaku pada nilai sosial. Nilainilai sosial sangat dijunjung tinggi karena sebagai patokan berbuat masyarakat. Menurut Abdulsyani, (1994:51) nilai merupakan patokan (standar) perilaku sosial yang melambangkan baik-buruk, benar salahnya suatu objek dalam hidup bermasyarakat.

Nilai merupakan kata jenis yang meliputi semacam genap kebaikan dan sejumlah hal lain. Nilai menurut Kattsoff (dalam Sagala, 2013:5), merupakan suatu kualitas objek atau perbuatan tertentu. Objek dan perbuatan tersebut akan didefinisikan berdasarkan atas nilai-nilai, tetapi tidak mungkin sebaliknya. Nilai adalah rujukan dan keyakinan dalam menentukan pilihan. Pengertian tersebut merupakan kesimpulan dari beberapa pengertian nilai diatas, dimaksudkan sebagai takaran manusia sebagai pribadi yang utuh atau nilai yang berkaitan dengan konsep benar atau salah yang di anut oleh golongan atau masyarakat tertentu. Karena orang tua mengetahui dan bisa menjelaskan makna Pancasila sila keadilan sosial bagi seluruh rakyat Indonesia serta bisa menjelaskan nilai-nilai yang terkandung dalam sila keadilan sosial bagi

sesama.

Keberadaan nilai sosial dalam karya sastra tidak lepas dari pandangan pengarang tentang nilainilai kebenaran yang di anutnya. Ajaran nilai sosial tersebut pada hakikatnya yang merupakan saran atau petunjuk agar pembaca memberikan respon atau mengikuti pandangan pengarang. Ajaran nilai sosial yang dapat diterima oleh pembaca biasanya yang bersifat umum, dalam arti tidak menyimpang dari kebenaran dan hak manusia. Pesan moral sastra lebih pada kodrati manusia yang hakiki, bukan pada aturan-aturan yang di buat, ditentukan, dan dihakimi manusia, (Nurgiyantoro, 1995:321). Fakta kemanusiaan merupakan landasan ontologisme dari strukturalisme genetik.Adapun yang dimaksudkan dengan fakta tersebut adalah segala hasil aktivitas atau perilaku manusia baik yang verbal maupun fisik, yang berusaha dipahami oleh ilmu pengtahuan. Fakta itu dapat terwujud aktivitas sosial tertentu seperti sumbangan bencana alam, aktivitas politik tertentu seperti pemilu, maupun kreasi kultural seperti filsafat, seni rupa, seni musik, seni patung, dan seni sastra. Meskipun dapat mempunyai wujud yang bermacam-macam, fakta-fakta sosial itu pada hakikatnya dapat dibedakan menjadi dua macam, yaitu fakta individual dan fakta sosial. Fakta yang kedua mempunyai peranan dalam sejarah, sedangkan fakta yang pertama tidak memiliki hal itu.Fakta pertama hanya merupakan hasil dari perilaku libidinal seperti mimpi, tingkah laku orang gila, dan sebagainya, sedangkan fakta pertama mempunyai dampak dalam hubungan sosial, ekonomi, maupun politik antar anggota masyarakat, (Farruk, 2012:57).

Pengarang dalam menyampaikan nilai sosial tidak selalu secara 
langsung atau dapat dikatakan pengarang selalu menceritakan kehidupan yang baik, hal ini agar tidak menimbulkan dan member kesan menggurui, juga untuk kepentingan keindahan, (Darma, 1995:42). Pernyataan tersebut memiliki pengertian bahwa karya sastra menawarkan kehidupan yang beraneka ragam, baik yang memiliki sifat baik maupun kurang baik. Bukan berarti pengarang menghendaki pembaca meniru perilaku kurang baik tersebut, tetapi sebaliknya hal tersebut jangan sampai di tiru oleh pembaca. Sistem nilai-nilai sangat penting bagi pergaulan hidup, oleh karena: (a) nilai merupakan abstraksi dari pengalaman-pengalaman pribadi seseorang (b) nilai-nilai tersebut senantiasa diisi dan bersifat dinamis, (c) nilai-nilai merupakan kriteria untuk memilih tujuan hidup, yang terwujud dalam perilaku.

Jenis Nilai Sosial yang sangat beragam dan kompleks yang ada di masyarakat, dapat diklasifikasikan menurut jenisnya sendiri. Beberapa jenis nilai sosial yang ada dalam masyarakat dapat dibedakan sebagai berikut:

Menurut Prof. Notonegoro, nilai sosial dibedakan menjadi tiga macam yaitu:

a. Nilai material yaitu, nilai yang terkandung dalam materi suatu benda yang berguna bagi kehidupan manusia. Sebagai contoh: bahan bangunan (pasir, batu-batuan) yang berguna untuk membuat rumah, gedung bertingkat, sekolah, dan lainlain.

b. Nilai vital adalah sesuatu yang berguna bagi manusia agar dapat melakukan aktivitas atau kegiatan dalam kehidupannya. Misalnya, komputer sebagai alat teknologi canggih yang membantu kegiatan administrasi di perkantoran. c. Nilai spiritual/rohani, yaitu suatu hal yang berguna untuk kebutuhan rohani. Dibagimenjadi empat, yaitu: 1). Nilai Religius merupakan nilai yang berisi filsafat-filsafat hidup yang dapat diyakini kebenarannya, misalnya nilai-nilai yang terkandung dalam kitab suci. 2). Nilai Estetika merupakan nilai keindahan yang bersumber dari unsur rasa manusia (perasaan atau estetika) misalnya, kesenian daerah atau penghayatan sebuah lagu. 3). Nilai Moral merupakan nilai mengenal baik buruknya suatu perbuatan misalnya, kebiasaan merokok pada anak sekolah. 4). Nilai Kebenaran/Empiris merupakan nilai yang bersumber dari proses berpikir menggunakan akal dan sesuai dengan fakta-fakta yang terjadi (logika/rasio) misalnya, ilmu pengetahuan bahwa bumi berbentuk bulat.

Persoalan manusia dalam hubunganya dengan manusia lain, Nurgiyantoro (1995:325) menyatakan bahwa masalah yang berupa hubungan kemasyarakatan, persahabatan dan kesetiaan, hubungan keluarga, cinta kasih orang tua terhadap anak, kakak terhadap adik dan lain sebagainya yang melibatkan interaksi antar manusia. Sementara itu dalam butir-butir Pancasila sila ke lima antara lain disebutkan saling peduli terhadap sesame dengan cara saling menolong, mengembangkan sikap tenggang rasa, gemar melakukan kegiatan sosial. Berdasarkan pada pengertian di atas, persoalan-persoalan yang berupa hubungan antar manusia antara lain adalah saling menyayangi, saling menolong, dan saling menasihati. Persoalan-persoalan tersebut mencakup hubungan kemasyarakatan dan kekeluargaan. 


\section{METODE PENELITIAN}

Penelitian ini bersifat deskriptif kualitatif karena penelitian ini dimaksudkan untuk memaparkan atau mengambarkan suatu hal secara obyektif atau apa adanya. Datadata yang telah terkumpul akan digambarkan dengan kata-kata atau kalimat sesuai dengan kategori untuk memperoleh kesimpulan. Adapun peneliti menggunakan penelitian yang bersifat kualitatif adalah sebagai berikut:

1. Penelitian deskriptif kualitatif memaparkan dan mengambarkan suatu hal secara obyektif atau apa adanya.

2. Hasil yang ingin dicapai adalah berupa model penelitian kualitatif.

3. Sumber data utama yang digunakan dalam penelitian ini ialah berupa sumber data tertulis yang ada dalam novel.

\section{HASIL DAN PEMBAHASAN}

Pada bab ini akan diuraikan secara rinci hasil penelitian terhadap novel Padang Bulan Karya Andrea Hirata, dengan menggunakan pendekatan analisis deskriptif. Hasil penelitian ini akan dikemukakan beberapa data yang diperoleh sebagai bukti hasil penelitian. Data yang akan disajikan pada bagian ini adalah data yang memuat nilai sosial sebagai salah satu unsur pembentuk novel tersebut.

\section{PEMBAHASAN}

Dari data yang dikemukakan diatas penelitian ini akan membahas bukti hasil penelitian. Data yang disajikan pada bagian ini adalah data yang memuat nilai sosial pada novel
Padang Bulan karya Andrea Hirata. Berdasakan metode yang digunakan penulis dalam menganalisis nilai sosial dalam novel Padang Bulan karya Andrea Hirata, maka dapat mengetahui nilai sosial apa saja yang disampaikan,

Kesabaran, tawakal, taat beribadah, penolong, rajin bekerja dan belajar, cinta kasih, dan kepedulian.

a. Kesabaran

Kesabaran adalah sebuah keutamaan yang menghiasi diri seorang mukmin, di mana seseorang mampu mengatasi berbagai kesusahan dan tetap berada dalam ketaatan kepada Allah meskipun kesusahan dan cobaan itu begitu dahsyat.

b. Tawakkal

Seseorang yang memiliki sifat tawakkal akan merasakan ketenangan, ketentraman, dan senantiasa merasa mantap dan optimis dalam bertindak. Di samping itu, juga akan mendapatkan kekuatan spiritual, serta keperkasaan luar biasa yang dapat mengalahkan segala kekuatan yang bersifat material. Juga merasakan kerelaan yang penuh atas segala yang dikehendaki dan dicitacitakannya.

c. Taat Beribadah

Ibadah merupakan tujuan akhir yang dicintai dan diridhai-Nya, karena Allah menciptakan manusia, mengutus para Rasul dan menurunkan kitab-kitab suciNya. Orang yang melaksanakannya dipuji dan yang enggan melaksanakannya dicela. Di antara keutamaan ibadah bahwasanya ibadah menyucikan jiwa dan membersihkannya, dan 
mengangkat ke derajat tertinggi menuju kesempurnaan manusiawi.

d. Penolong

Sebagai mahluk sosial, manusia tidak dapat hidup sendirian. Meski segalanya telah dimiliki, harta benda yang berlimpah sehingga setiap yang telah diinginkan maka dengan mudah dapat terpenuhi, tetapi jika hidup sendirian tanpa orang lain yang menemani tentu akan kesepian pula. Kebahagiaan pun tak pernah dirasakan.

e. Rajin Bekerja dan Belajar Dengan bekerja keras seseorang atau setiap manusia akan mendapatkan yang diinginkan meski dalam melakukannya bersusah payah. Tidak hanya bekerja keras yang diutamakan, tetapi juga harus diimbangi dengan rasa ikhlas. Karena dengan rajin bekerja keras dan belajar yang diimbangi dengan rasa ikhlas maka akan terlihat mudah.

f.

Cinta terhadap bahasa ialah rasa sangat kasih saying atau sangat tertarik hatinya. Adapun dari segi bahasa adalah ungkapan perasaan jiwa, ekspresi hati dan gejolak naluri yang menggelayuti hati seorang terhadap kekasihnya. Sedangkan menurut Kahlil Gibran, cinta ialah perasaan untuk dirinya sendiri. Cinta ialah kekuatan manusia yang paling tinggi. Cinta adalah sumber segalanya, kita tidak akan mewujudkan setiap impian kita tanpa cinta. Pada dasarnya kasih saying adalah fitrah yang dianugrahkan oleh Tuhan kepada mahluknya, misalnya hewan, kita perhasilkan begitu kasihnya kepada anaknya, sehingga rela berkorban hingga anaknya diganggu. Naluri inipun ada pada manusia, dimulai dari kasih sayang orang tua kepada anaknya, begitu pula sebaliknya.

g. Kepedulian

Kepedulian merupakan wujud nyata dari empati dan perhatian. Ketika kita bersikap terbuka kepada orang lain, maka kita dapat menghadapi masa-masa sulit dengan kreativitas dan ketegaran. Empati mendorong kita untuk menjalin hubungan dengan orang lain. Empati akan muncul ketika kita memulai rasa ingin tahu kita terhadap orang lain dan pengalaman-pengalaman mereka. Kemudian empati itu akan diwujudkan ke dalam bentuk tindakan. Kepedulian didasarkan pada hasrat secara penuh untuk membina ikatan dengan orang lain dan untuk memenuhi kebutuhan mereka. Namun bagaimanapun cara terbaik untuk memahami apa itu kepedulian adalah dengan cara melihat bagaimana kepedulian tersebut dipraktikan.

Salah satu nilai sosial dalam novel Padang Bulan Karya Andrea Hirata pada kutipan berikut,

“ Ke hadapan kawanku, Ikal... Melalui Jose Rizal, kusampaikan betapa aku merasa bersedih atas kesusahan yang menimpamu. Aku tahu kau merana. Aku tahu kau tersiksa. Cinta, memang kejam tak terperi. Tapi, aku di sini, kawanku, siap sedia membantumu, dan aku punya informasi lebih mendalam soal ini. Aku telah mengenal 
sainganmu itu. Tegakan badanmu, tabahkan hatimu... Detektif M. Nur, kawanku... Terima kasih atas kebaikanmu yang telah membesarkan hati yang sengsara ini. Suratmu sungguh telah melapangkan dadaku. Betapa mulia hatimu. Surge, itulah ganjaran yang mahatinggi untuk orang sepertimu.

Dari kutipan di atas menggambarkan bahwa sikap penolong dan kepedulian yang sangat agung terhadap seorang teman, Detektif M.Nur menggambarkan sikap yang sangat peduli dengan keadaan temannya yang sedang patah hati.

\section{SIMPULAN}

Berdasarkan hasil analisis data dari novel Padang Bulan karya Andrea Hirata. Nilai sosial adalah nilai yang dianut oleh suatu masyarakat, mengenai apa yang dianggap baik dan apa yang dianggap buruk oleh masyarakat. Untuk menentukn sesuatu itu dikatakan baik atau buruk, pantas atau tidak pantas harus melalui proses menimbang. Hal ini tentu sangat dipengaruhi oleh kebudayaan yang dianut masyarakat. Tak heran apabila antara masyarakat yang satu dan masyarakat yang lain terdapat perbedaan tata nilai. Berdasarkan hasil penelitian dalam novel Padang Bulan karya Andrea Hirata, nilai sosial yang terjadi dalam novel tersebut adalah kesabaran, tawakal, taat beribadah, penolong, rajin bekerja dan belajar, cinta kasih, dan kepedulian.

Dari ketujuh nilai tersebut menggambarkan nilai sosial yang ada dalam novel Padang Bulan karya Andrea Hirata yaitu dalam bentuk kerja keras, gotong royong, rela berkorban, dalam kehidupan bermasyarakat. Pada keseluruhan dalam novel Padang Bulan karya Andrea Hirata yang telah dianalisis nila isosialnya kebanyakan bertemakan memperjuangkan hidup demi keluarga. Kehadiran Enong untuk membantu dan rela berkorban untuk menghidupkan keluarga yang tercintanya dari penderitaan dan menekankan dalam proses perjuangan hidup.

\section{SARAN}

Berdasarkan simpulan yang disajikan oleh penulis, yaitu penelitian mengenai“" Nilai Sosial Pada Novel Padang Bulan Karya Andrea Hirata" dapat dikemukakan beberapa saran kepada berbagai lapisan masyarakat sebagai berikut.

1). Saran untuk mahasiswa jurusan Pendidikan Bahasa Dan Sastra Indonesia hendaknya melestarikan sastra dan mengembangkannya dengan melalui pendekatan moral maupun pendekatan lainnya.

2). Saran untuk penikmat sastra, bacalah sastra dengan mengahayati dan memahami apa yang ingin disampaikan pengarang dalam karyanya.

3). Saran untuk pembaca yang akan melakukan penelitian di bidang yang sama, jika menggunakan skripsi ini sebagai referensi, maka kiranya perlu dikaji kembali. Karena tidak menutup kemungkinan ada pernyataanpernyataan yang belum sesuai, karena saya sebagai penulis merasa masi banyak kekurangan dan keterbatasan dalam menyelesaikan skripsi ini.

4). Saran untuk guru bahasa dan sastra Indonesia hendaknya dapat memaksimalkan penggunaan bahan pembelajaran sastra, dalam 
hal ini adalah novel. Novel Padang Bulan karya Andrea Hirata ini didalamnya memenuhi empat macam manfaat pembelajarn sastra yaitu: membantu keterampilan berbahasa, meningkatkan pengetahuan budaya, mengembangkan ciptadan rasa, dan menunjang pembentukan watak. Lebih lanjut guru dapat memilih novel lain yang sekiranya terdapat beberapa cakupan yang bisa memberikan manfaat positif bagi siswa, sehingga siswa tidak hanya memperoleh hiburan saja tetapi juga mendapatkan ilmu kehidupan.

5). Saran untuk orang tua dalam membimbing karakter anak harus selalu diperhatikan dan senantiasa dibimbing agar anak tumbuh dengan kepribadian yang baik.

\section{DAFTAR PUSTAKA}

Anwar. Shoim. 2013. Sastra Lama. Sidoarjo: Media Ilmu.

Arikunto.Suharsimi. 2010. Prosedur Penelitian suatu Pendekatan Praktik. Jakarta: Rineka Cipta.

Faruk.2012. Pengantar Sosiologi Sastra dari Strukturalisme Genetic sampai Post Modernisme. Yogyakarta: Pustaka Pelajar.

Kasnadi.Sutejo. 2011. Sosiologi Sastra Menguak Dimensionalitas Sosial dalam Sastra. Yogyakarta: Spectrum. Pustaka Felicha.

Rafiek. 2013. Pengkajian Sastra Kajian Praktis. Bandung: Rafika Aditama.

Sagala, Syaiful. 2013. Etika dan Moralitas Pendidikan Peluang Dan Tantangan. Solo: Kencana.
Saryono, $\quad$ Djoko. 2009. DasarApresiasiSastra. Yogyakarta: Elmatera Publishing

Setiadi. Hakam. Effendi.2007. Ilmu Sosial dan Budaya Dasar. Jakarta: Kencana. 